\section{Upcoming Meetings/Réunions à venir}

Western Forestry Conference, December 5-7, 1993.

Seattle, Wash. Contact: Christy Dorsey, Western Forestry/Conservation Assoc., 4033 SW Canyon Rd., Portland, OR 97221. Tel. (503) 226-4562.

Ontario Forestry Association Annual Meeting and Auction, February 4-5, 1993.

Radisson Hotel, Don Mills, Ontario. Contact: OFA, Tel. (416) 493-4565, Fax (416) 493-4608.

86th Annual Canadian Lumbermen's Assoc. Convention, February 9-11, 1994.

Montreal. Contact: CLA, Tel. (613) 223-6205.

46th Annual General Meeting, Association of BC Professional Foresters. February 16-18, 1994.

Duncan, BC. Theme 'BC'S Forests: Our Common Wealth". Contact: ABCPF, 440-789 West Pender St., Vancouver, BC V6C 1H2. Tel. (604) 687-8027, Fax (604) 687-3264.

The Fourth Dimension. Eighth Annual Symposium and Exposition On Geographic Information Systems, February 21-24, 1994.

Vancouver, BC. Decision making with GIS: The Fourth Dimension. Increasing complexity. Uncertain solutions. Conflicting options. Contact: GIS '94 Symposium Office, Suite 207, 1102 Homer Street, Vancouver, BC V6B 2X6. Toll free Fax 1-800-661-0044, Tel. (604) 688-0188.

Environmental Stewardship: History, Theory and Practice. March 10-11, 1994.

Winnipeg, Manitoba. Contact: Nancy Ito, Administrative Officer, Institute of Urban Studies, 515 Portage Ave., Winnipeg, Manitoba R3B 2E9. Tel. (204) 786-9409, Fax (204) 786-1824.

International Short Course in Forest Genetics and Tree Improvement. March 14-25, 1994. North Carolina State University, Raleigh, North Carolina, USA. For further information: Ann Coughlin, North Carolina State University, College of Forest Resources, Box 8001, Raleigh, NC 27695-8001, USA. Fax (919) 515-7231.
The International Land Reclamation and Mine Drainage Conference and the Third International Conference on Abatement of Acidic Drainage, April 25-29, 1994.

Pittsburgh, Pennsylvania, USA. Contact: Debbie Lowanse or Bob Kleinmann, US Bureau of Mines, P.O. Box 18070, Pittsburgh PA 15236, USA. Tel. (412) 892-6708, Fax (412) 892-4067.

Ecostem Monitoring and Protected Areas. May 16-20, 1994.

Second International Conference on Science and the Management of Protected Areas. Dalhousie University, Halifax, Nova Scotia, Canada. Contact: Mr. Neil Munro, Director, Policy Planning and Research, Canadian Parks Service, Environment Canada, Historic Properties, Upper Water Street, Halifax, Nova Scotia, Canada, B3J 1S9 or Fax (902) 426-7012.

Global to Local: Ecological Land Classification. August 15-17, 1994. symposium will consist of: plenary and break-out presentation sessions, poster sessions and displays, a one-day field tour, and other pre/post conference tours and activities. For further inforThunder Bay, Ontario. The three-day

\section{Publications of Interest}

UNB Faculty of Forestry - 1992. The Year Under Review. Edited by Alex Dickson. Based largely on columns contributed to The Forestry Chronicle. $15 \mathrm{p}$.

The Forintek Partnership: Progress \& Achievements 1992-1993. Forintek Canada Corp. The publication includes sections on market support, manufacturing, the resource and technical services and training. A list of 19921993 publications is included. 25 p. plus appendices.

1992 Annual Report. Faculty of Forestry, The University of British Columbia. Includes the following chapters: Dean's message, staff lists and achievements for each department, offices, awards and distinctions, sponsored research, faculty publications, mation, contact: Dr. R. A. Sims, Chairperson: ELC Steering Committee, Forestry Canada - Ontario Region, P.O. Box 490, 1219 Queen Street East, Sault Ste. Marie, ON P6A 5M7. Tel. (705) 949-9461, Fax (705) 759-5700.

Decision Support - 2001. September 12-16, 1994.

International Symposium on Advanced Technology in Natural Resource Management, Toronto, Ontario, Contact: Mike Power, Forestry Canada (613) 589-2880, Chalk River, Ontario, Canada, K0J $1 \mathrm{~J} 0$ or Sindy Coley, Resource Technology Institute, $140 \mathrm{~W}$. Oak, Suite 211, Fort Collins, CO, USA 80524 (303) 490-1688.

Integrating Social and Ecological Perspectives to Sustain Forest Health. October 11-13, 1994.

Coeur d'Alene, Idaho. Sponsored by US Forest Service, Society of American Foresters, International Union of Forestry Research Organizations and Western Forestry and Conservation Association. Contact: Richard Zabel, Western Forestry and Conservation Association, 4033 SW Canyon Road, Portland, Oregon 97221. Tel./Fax (503) 226-4562.

NOTE: Papers or posters are solicited. All inquiries must be received by December 6, 1993. special lectures, university research forests, international programs, Centre for Applied Conservation Biology, BC Forestry Continuing Studies Network, programs of study, undergraduate programs and graduate programs.

Forest Round Table on Sustainable Development. A Progress Report. March 1993. National Round Table on the Environment and the Economy. Bilingual tumble format. $12 \mathrm{p}$.

Final Report. Cabinet Committee on the North American Free Trade Agreement. June 1993. Government of Ontario, 79 p.

Proceedings: Pulpmill Waste Utilization in the Forest, a conference held in Edmonton, Alberta Canada, April 19, 1993. Comp. Clear Lake Ltd. 